\title{
Synthesis of Primary Amines with OMS-2
}

\section{Key words}

amides

manganese oxide

heterogeneous

catalysis

SYNFACTrenth<smiles>NC(=O)c1ccccc1</smiles>

$3 \mathrm{~h}, 96 \%$ yield<smiles>NC(=O)c1ccc2ccccc2c1</smiles>

$3 \mathrm{~h}, 95 \%$ yield aq $\mathrm{NH}_{3}$

(ca. 2.6 equiv)

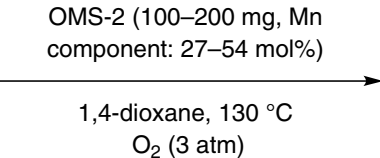

$\mathrm{O}_{2}$ (3 atm)
(1)

21 examples $45-97 \%$ yield<smiles>COc1ccc(C(N)=O)cc1</smiles>

$3 \mathrm{~h}, 98 \%$ yield<smiles>NC(=O)c1ccsc1</smiles>

$3 \mathrm{~h}, 87 \%$ yield<smiles>NC(=O)c1ccc(Cl)cc1</smiles>

$3 \mathrm{~h}, 97 \%$ yield<smiles>NC(=O)c1ccccn1</smiles>

$1 \mathrm{~h}, 95 \%$ yield<smiles>COc1cccc(C(N)=O)c1</smiles>

$3 \mathrm{~h}, 96 \%$ yield<smiles>[13CH][13CH]C(N)=O</smiles>

$24 \mathrm{~h}, 65 \%$ yield

Syntheses of amides from aldehydes and nitriles:

$$
\begin{array}{cc}
\mathrm{R}-\mathrm{X} & +\quad \\
\mathrm{X}=\mathrm{CHO}, \mathrm{CN} \\
(0.5 \mathrm{mmol})
\end{array}
$$

Selected examples:<smiles>NC(=O)c1ccccc1</smiles>

$3 \mathrm{~h}, 89 \%$ yield $(\mathrm{X}=\mathrm{CHO})$ $3 \mathrm{~h}, 91 \%$ yield $(\mathrm{X}=\mathrm{CN})$<smiles>NC(=O)/C=C/c1ccccc1</smiles>

$3 \mathrm{~h}, 87 \%$ yield $(\mathrm{X}=\mathrm{CHO})$ $3 \mathrm{~h}, 93 \%$ yield $(\mathrm{X}=\mathrm{CN})$

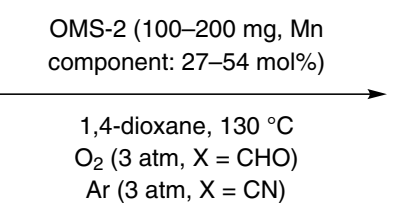

$\operatorname{Ar}(3 \mathrm{~atm}, \mathrm{X}=\mathrm{CN})$<smiles>NC(=O)c1ccccn1</smiles>

$1 \mathrm{~h}, 94 \%$ yield $(\mathrm{X}=\mathrm{CHO})$ $1 \mathrm{~h}, 96 \%$ yield $(\mathrm{X}=\mathrm{CN})$<smiles>[R]C(N)=O</smiles>

16 examples $77-98 \%$ yield<smiles>CCCCCCCC(N)=O</smiles>

$24 \mathrm{~h}, 77 \%$ yield $(\mathrm{X}=\mathrm{CHO})$ $24 \mathrm{~h}, 98 \%$ yield $(\mathrm{X}=\mathrm{CN})$
Significance: Manganese oxide based octahedral molecular sieves (OMS-2) catalyzed the reaction of primary alcohols with aqueous ammonia to give the corresponding amides in 65-99\% yield under molecular oxygen (10 examples, eq. 1). The reactions of aldehydes and nitriles with aqueous ammonia also proceeded in the presence of OMS-2 to give the corresponding amides in 77$98 \%$ yield (16 examples, eq. 2). In the formation of 2-pyridinecarboxamide from 2-pyridinemethanol, the catalyst was recovered by filtration and reused eleven times without significant loss of its catalytic activity ( $1^{\text {st }}$ reuse: $93 \%$ yield, $11^{\text {th }}$ reuse: $85 \%$ yield).
Comment: Suib and co-workers have previously reported the preparation of OMS-2 (Chem. Mater. 1994, 6, 815). In the formation of benzamide from benzyl alcohol, the catalytic activity of OMS-2 was superior to that of precursors of OMS-2 $\left(\mathrm{KMnO}_{4}\right.$, $\mathrm{MnSO}_{4} \cdot \mathrm{H}_{2} \mathrm{O}$ ), other manganese-based oxides $\left(\mathrm{MnO}_{2}\right.$ and $\left.\mathrm{Mn}_{3} \mathrm{O}_{4}\right)$ and other metal oxides $\left(\mathrm{Co}_{3} \mathrm{O}_{4}, \mathrm{CeO}_{2}\right)$. After the reaction of benzyl alcohol with aqueous ammonia, no leaching of manganese species was observed by ICP-AES analysis. 